\title{
Skarn zonation and rock physical properties of the Wondong Fe-Pb-Zn polymetallic deposit, Korea
}

\author{
Eui-Jun Kim \\ Korea Institute of Geoscience and Mineral Resources, Daejeon 305-350, Republic of Korea \\ Dongbok Shin* \\ Department of Geoenvironmental Sciences, Kongju National University, Gongju 314-701, Republic of Korea \\ Seungwook Shin \\ Hyeong-Tae Nam Korea Institute of Geoscience and Mineral Resources, Daejeon 305-350, Republic of Korea \\ Samgyu Park
}

\begin{abstract}
The Wondong Fe-Pb-Zn polymetallic skarn deposit is located in the Taebaeksan Basin, South Korea. This deposit is associated with the Paleocene quartz porphyry and characterized by abundant exoskarn and subordinate endoskarn. A general zonation pattern is developed comprising a proximal reddish-brown garnet-rich zone, a distal greenish garnet \pm pyroxene zone, and a wollastonite-rich zone at the marble front. The mineralization is characterized by $\mathrm{Fe}$ in the proximal garnet-rich zone and $\mathrm{Pb}-\mathrm{Zn}$ within and beyond the garnet \pm pyroxene zone. In general, skarn deposits show complex geophysical signatures in their rock properties in relation to metasomatism. Garnet-rich and garnet \pm pyroxene skarns accompanying Fe-oxides and sulfides are significantly denser $\left(3.3-3.4 \mathrm{~g} / \mathrm{cm}^{3}\right)$ than the other rocks $\left(2.5-3.0 \mathrm{~g} / \mathrm{cm}^{3}\right)$ such as quartz porphyry, wollastonite-rich skarn, and silicic hornfels. Reactions related to creating garnet may increase porosity, which promotes further infiltration and reaction to produce garnet growth. The porosity of skarn rocks $(1.8-8.4 \%)$ has a broad range and is generally higher than the other rocks $(0.8-3.3 \%)$. In contrast, most skarn rocks show a remarkably low electrical resistivity (mostly 211-848 $\Omega m)$ than the other rocks $(1,815-8,601 \Omega m)$. Magnetic susceptibilities of skarn rocks $\left(15-140 \times 10^{-5} \mathrm{SI}\right)$ are higher than quartz porphyry and siliceous hornfels $\left(<25 \times 10^{-5} \mathrm{SI}\right)$. $\mathrm{P}$ wave velocities in the garnet \pm pyroxene zone at the skarn front show lower values $(1,487-3,674 \mathrm{~m} / \mathrm{s})$ than the other rocks $(2,902-5,590 \mathrm{~m} / \mathrm{s})$, which is likely related to the porosity of the rocks. Thus, in general, the physical properties of rocks as exampled above from the skarn environment reflect their mineral assemblages and can be used for mineral exploration of skarn deposits.
\end{abstract}

Key words: Wondong skarn deposit, skarn zonation, Fe-Pb-Zn mineralization, rock physical properties

\section{INTRODUCTION}

Skarn deposits are formed by metasomatism which results from the transfer of heat and fluid from intrusive rocks to surrounding rocks, leading to early calc-silicate alteration followed by oxide-sulfide mineralization. The alteration mineral assemblages in most calcic skarn deposits are zoned from a proximal garnet-rich zone, through distal pyroxene-rich zone,

*Corresponding author: shin@kongju.ac.kr and to pyroxenoid-rich zone (wollastonite, bustamite, or rhodonite), in relation to associated intrusions (Meinert, 1997), and mineralization generally occurs within and beyond the skarn. Although there are many skarn deposits in South Korea, well-developed zonation patterns have not been identified due to poor exposure in most deposits. Thus, the zonation model cannot be used in exploration for blind targets. As an alternative, geophysical methods are thought to be the most suitable tools for buried skarn deposits. Several researchers have reported physical properties of plutons in porphyry deposits (Spector, 1972; Ishihara, 1977) and oxide-sulfide ore bodies in skarn deposits (Chapman and Thompson, 1984; Emerson, 1986; Emerson and Welsh, 1988; Hoover and Knepper, 1992; Peng and Zhao, 1998). But most researchers have not paid attention to the geophysical properties of rocks from the skarn environment.

This paper characterizes calc-silicate alteration assemblages, zonation patterns, and mineralization, and then examines geophysical properties of rocks from the Wondong deposit in the Taebaeksan Basin, South Korea, to discuss the implications of geophysical properties of skarn rocks for mineral exploration.

\section{GEOLOGICAL BACKGROUND}

\subsection{Regional Geology}

The Taebaeksan Basin is located in the northeastern part of the Ogcheon Fold Belt, and its stratigraphic units consist mainly of Cambrian-Ordovician Joseon Supergroup and Carboniferous-Triassic Pyeongan Supergroup (Chough et al., 2000). The Joseon Supergroup disconformably overlies the Precambrian metasedimentary rocks (Yeongnam Massif) and is composed mostly of thick carbonates. It has been subdivided into five types based on distinct lithologic sequences and distribution: Taebaek, Yeongwol, Yongtan, Pyeongchang, Moonkyeong types (Choi, 1988). The Pyeongan Supergroup consists mainly of a thick clastic succession that formed 


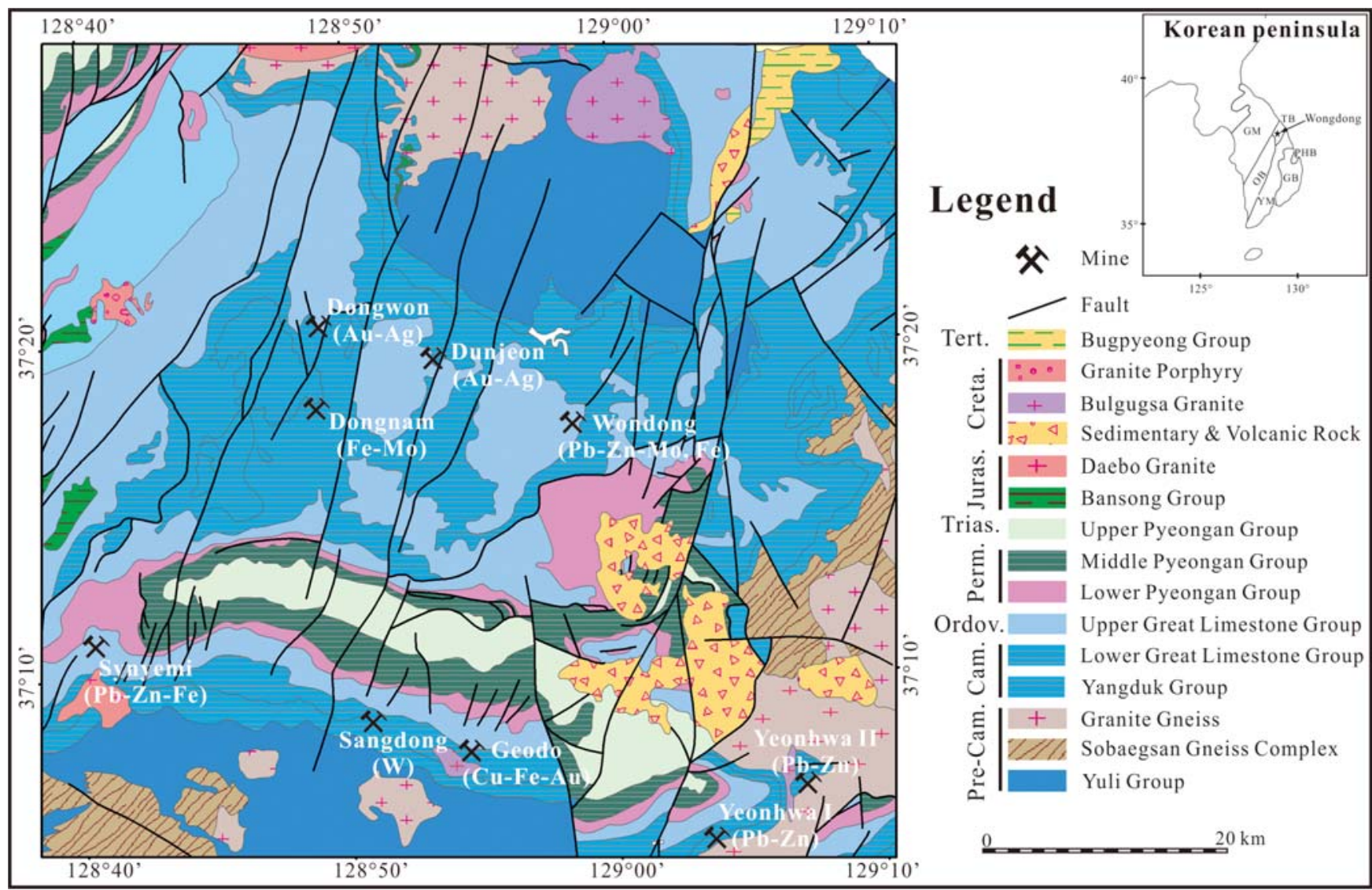

Fig. 1. Regional geologic map showing distribution of various types of metallic deposits in the Taebaeksan Basin, South Korea (after GICTR, 1962). Abbreviations: $\mathrm{GM}=$ Gyeonggi Massif, $\mathrm{OB}=$ Ogcheon Belt, $\mathrm{TB}=$ Taebaeksan Basin, $\mathrm{YM}=$ Yeongnam Massif, $\mathrm{GB}=$ Gyeongsang Basin, $\mathrm{PHB}=$ Pohang Basin.

mostly in shallow marine and fluvial environments and contains the economically significant coal resources of South Korea (Chough et al., 2000). The Taebaeksan Basin hosts a variety of skarn deposits (Shinyemi Pb-Zn-Fe, Sangdong W, Geodo $\mathrm{Cu}-\mathrm{Fe}-\mathrm{Au}$, Yeonhwa I-II Pb-Zn, Dongwon Au-Ag, Dongnam Fe-Mo, Dunjeon Au-Ag, Wondong Pb-Zn-Mo-Fe deposits; Fig. 1).

\subsection{Local Geology and Skarn Rocks}

The Wondong deposit is located in the northern Taebaeksan Basin which is divided into northern and southern parts bordered by the ENE-WNW trending Wondong thrust fault (Fig. 2). The northern part consists mostly of the Pungchon and Hwajeol formations of Cambrian-Ordovician age, while the southern part includes the Maggol formations bordered by Carboniferous Pyeongan Supergroup (Fig. 2). The Pungchon formation comprises oolitic, argillaceous, and brecciated limestone and conglomerate, and the overlying Hwajeol formation is dark grey shale and limestone. The Maggol formation consists of lenticular or massive dolomitic limestone and dolomite (Chi et al., 2011).

Quartz porphyry extensively exposed in the Wondong deposit intruded into Cambrian-Ordovician carbonate units and produced a large skarn zone comprised of garnet-rich zone, garnet \pm pyroxene zone, and wollastonite-rich zone at the contact zone (Figs. 3-5). The quartz porphyry has a U-Pb zircon age of $79.37 \pm 0.94 \mathrm{Ma}$, while K-Ar ages of phlogopite dated between $49.1 \mathrm{Ma}$ and $49.9 \mathrm{Ma}$ indicate the timing of skarn mineralization (Park et al., 2013). Quartz porphyry was cut by ore-bearing veinlets (Figs. 5a and b). Quartz phenocrysts of the quartz porphyry in the drill core are approximately $5 \mathrm{~mm}$ in length and occur as euhedral or subhedral crystals. The feldspar in the quartz porphyry intrusion is partially replaced by calcite (Fig. 6a), and occasionally replaced by ore minerals such as chalcopyrite, magnetite, and scheelite with lesser sphalerite and galena. The abundance of quartz phenocrysts decreases markedly from the core toward the contact with skarn (Figs. $5 \mathrm{a}$ and $\mathrm{b})$. The porphyritic texture is interpreted to result from temperature quenching during the intrusion of magma into relatively cold country rocks, or pressure quenching after fluid escape.

Skarn in the Wondong deposit is characterized by abundant exoskarn developed into the Maggol formation and lesser endoskarn. The contact zone between the quartz porphyry and the skarn is mostly sharp, and the mineralization is poor 


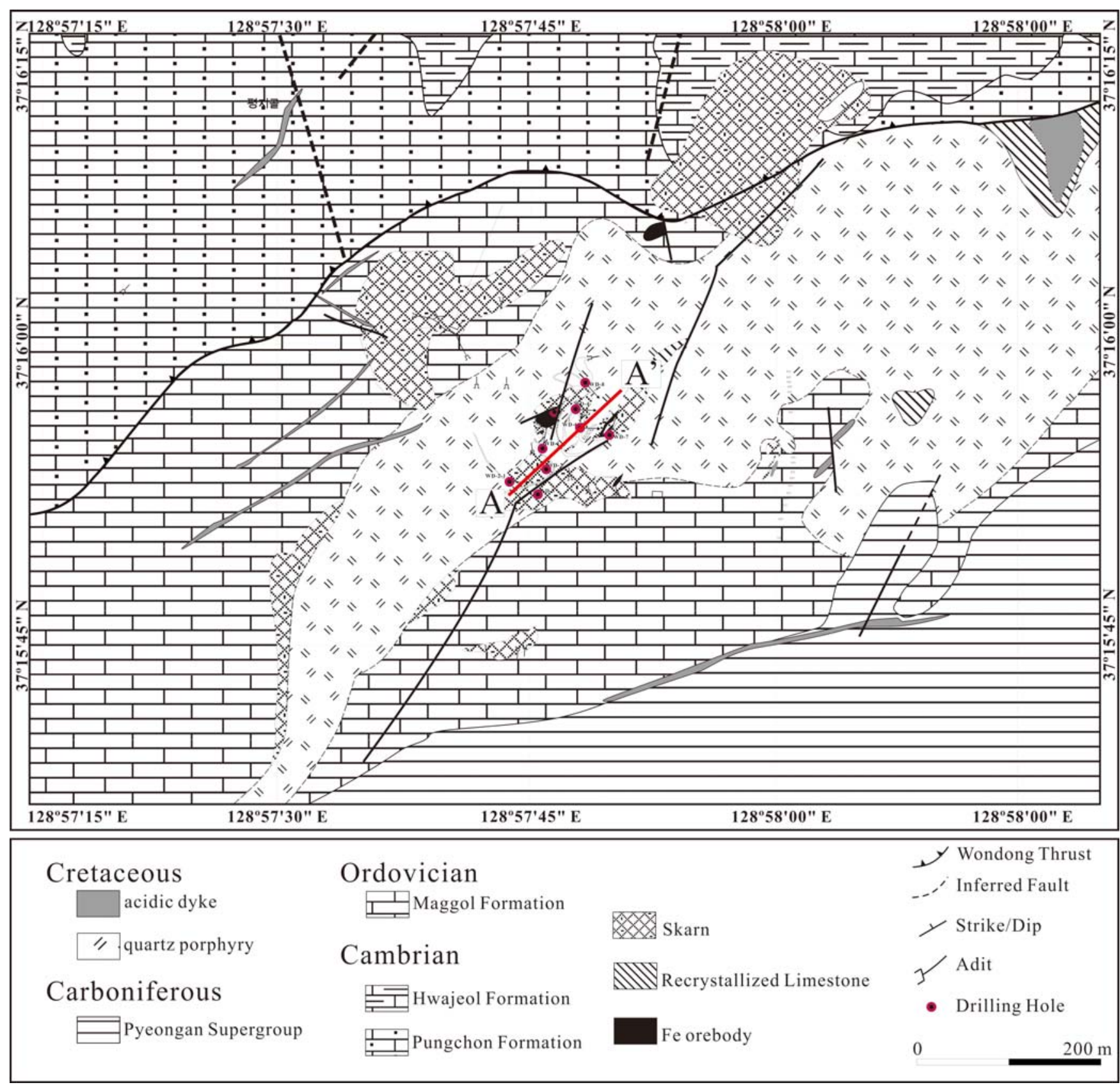

Fig. 2. Local geologic map of the Wondong deposit showing the distribution of skarn and ore body associated with quartz porphyry (after Kim et al., 1993).

at this zone (Figs. 3-4). It implies that the contact zone would have played a role as migration conduit for hydrothermal fluids. $\mathrm{Pb}-\mathrm{Zn}$ ores generally occur as stratiform replacement ore within the Maggol formation with $10-50 \mathrm{~cm}$ in width and 5-20 $\mathrm{m}$ in length (Fig. 3).

Based on outcrop exposures and drill cores, a general zonation pattern of the exoskarn is recognized, comprising a proximal reddish-brown garnet-rich zone, a distal greenish garnet \pm pyroxene zone, and a wollastonite-rich zone at the marble front (Figs. 4-5). The garnet/pyroxene ratios decrease with increasing distance from the quartz porphyry, and pyrox- ene-rich skarn is much narrower than the garnet-rich skarn. The proximal garnet-rich skarn consists mostly of grandite and is characterized by garnet with sector and oscillatory growth zoning (Fig. 6b). Garnet also shows systematic color variation from the skarn to the marble front. The proximal garnet is reddish-brown (Fig. 5c), whereas the distal garnet is light brown to yellow-green near the marble front (Fig. 5d). The garnet is partially altered to calcite and hematite, with calcite-filled boundaries between individual garnet crystals. Electron microprobe analyses revealed that the garnet belong to grossular-andradite series (Table 1). 


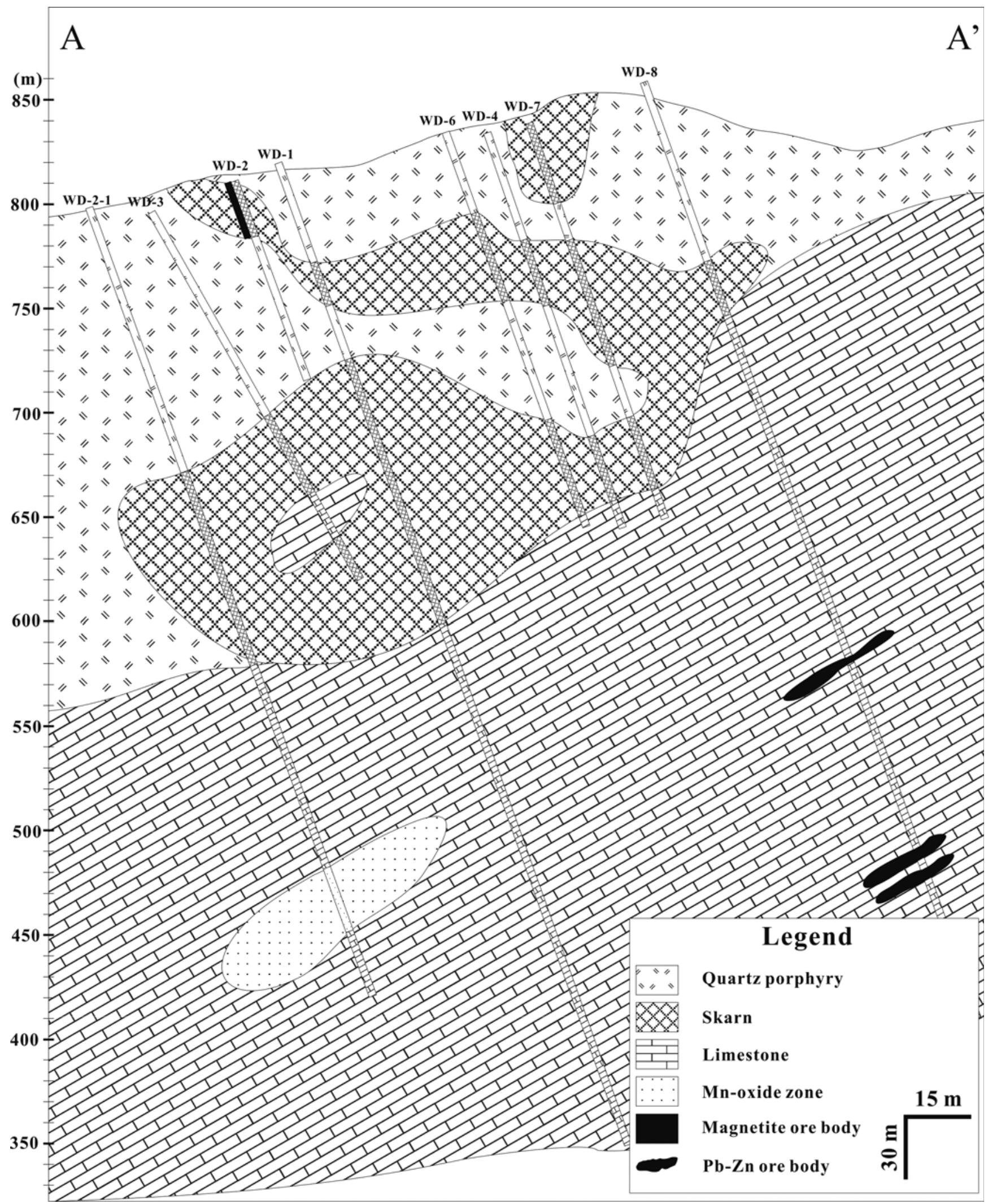

Fig. 3. Lithological cross section of the Wondong deposit for A-A' in Figure 2.

In contrast, pyroxene is relatively lesser in the Wondong deposit, although it is abundant in most skarn deposits. Dis- tal pyroxene is rather perpendicular to the direction of garnet growth, suggesting that the pyroxene was probably precip- 

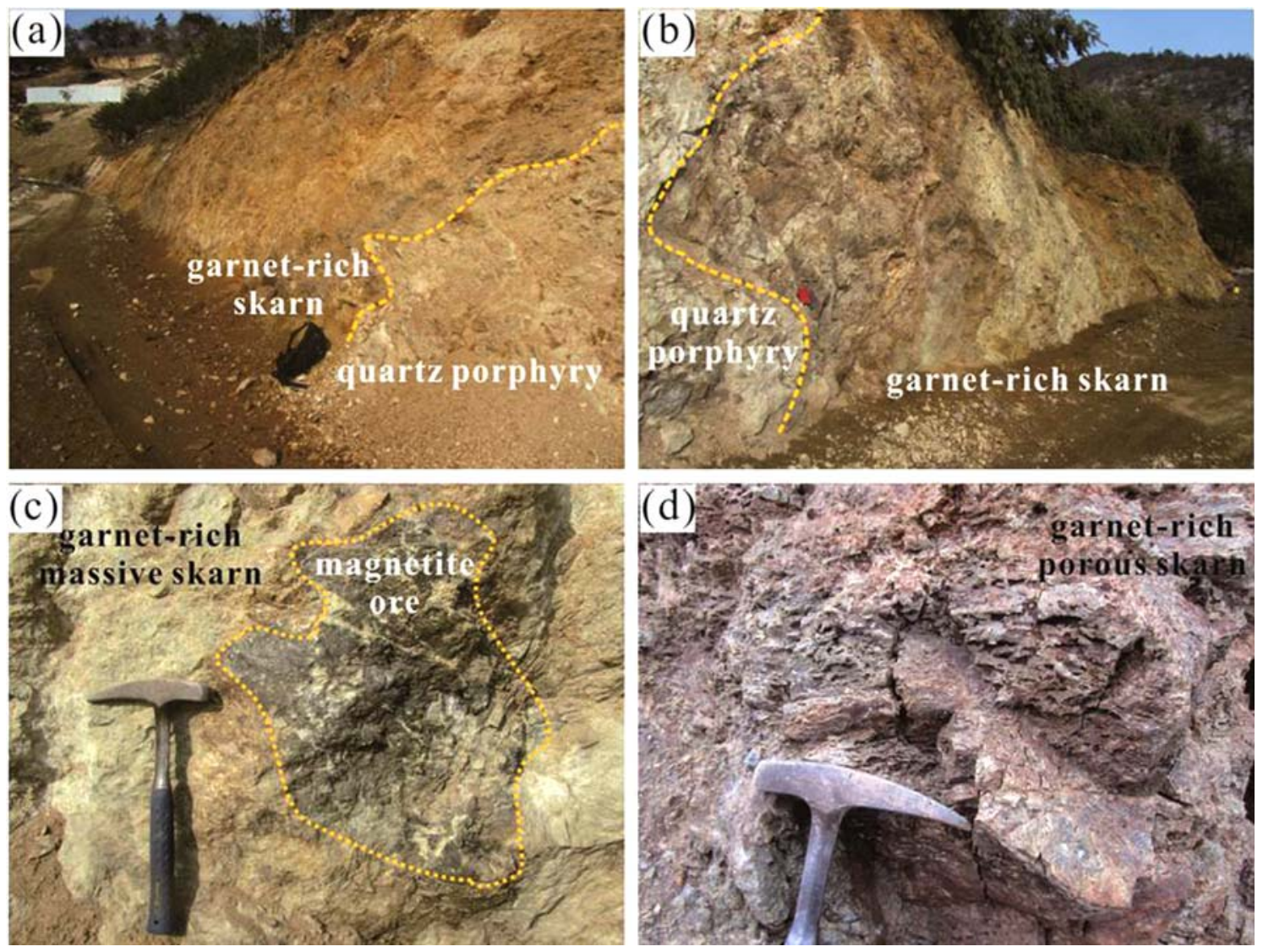

Fig. 4. Outcrop images of intruding quartz porphyry and resulting garnet-rich skarn in the Wondong deposit. (a and b) Contact zone between quartz porphyry and garnet-rich skarn. (c) Proximal massive garnet-rich skarn with magnetite orebody. (d) Distal garnet-rich skarn with a lot of cavities.

itated slightly later than the garnet. The distal garnet \pm pyroxene zone has many cavities (Fig. 5d), and some cavities were also observed in the proximal garnet-rich skarn. The compositional range of the pyroxene obtained by electron microprobe analyses corresponds to diopside-hedenbergite series (Table 2). Beyond the garnet-rich and garnet \pm pyroxene zones, the wollastonite-rich zone (Fig. 5e) has a sharp contact with garnet \pm pyroxene skarn, but green garnet veins extend into the wollastonite-rich zone from the garnet \pm pyroxene zone. Beyond the skarn, silicic hornfels is developed (Fig. 5f).

The paragenetic sequence of the polymetallic skarn consists of early calc-silicate alteration and later mineralization stage, which mostly occurs within and beyond skarn in the Wondong deposit (Fig. 7). The mineralization is characterized by magnetite which occurs as massive, banded, and disseminated form in the proximal garnet-rich zone, and by sphalerite and galena which occur as veins in the garnet \pm pyroxene zone and as mantos beyond the wollastonite-rich zone (Chi et al., 2011).

\section{METHODS}

\subsection{Porosity and Density}

The porosity and density of rocks from the Wondong deposit were measured using water evaporation and buoyancy methods (International Society for Rock Mechanics, 1979). Porosity is the ratio of pore volume to its total volume and was measured by using formula (1). It is generally controlled by rock type, grain size, pore distribution, and cementation. The types of geologic porosities include primary, secondary, fracture, and vuggy porosities, of which fracture and vuggy porosities are classified as secondary porosity. The density was calculated by using formula (2):

$$
\begin{aligned}
& n=\frac{V_{v}}{V} \times 100=\frac{M_{\text {sat }}-M_{s}}{M_{\text {sat }}-M_{\text {sub }}} \times 100, \\
& \rho_{\text {sat }}=\frac{M_{\text {sat }}}{M_{\text {sat }}-M_{\text {sub }}},
\end{aligned}
$$

where, $\mathrm{n}$ is effective porosity (\%), $\mathrm{V}$ is bulk sample volume $\left(\mathrm{cm}^{3}\right), V_{\mathrm{v}}$ is void volume $\left(\mathrm{cm}^{3}\right), \mathrm{M}_{\text {sat }}$ is saturated-surface-dry mass (g), $M_{s}$ is grain mass (g), $M_{\text {sub }}$ is saturated-submerged mass $(\mathrm{g}), \rho_{\text {sat }}$ is saturated density $\left(\mathrm{g} / \mathrm{cm}^{3}\right)$.

Specimens were completely dried to constant mass at a temperature of $110{ }^{\circ} \mathrm{C}$ for 24 hours to measure $\mathrm{M}_{\mathrm{s}}$. Secondly, they were saturated by water immersion $(0.001 \mathrm{~mol}$ solution of sodium chloride) in a vacuum of 0.05 torr for 48 hours, and then the $\mathrm{M}_{\text {sub }}$ of specimens was measured with a hanging 

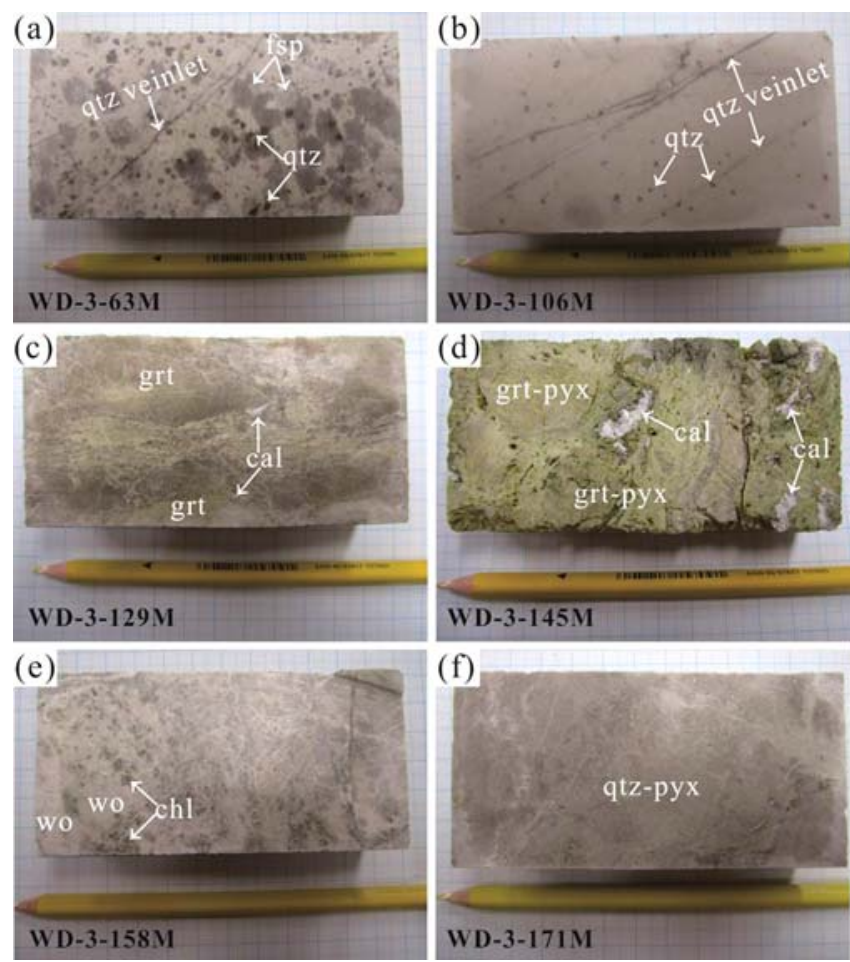

Fig. 5. Rock types of drill cores in the Wondong deposit. The core (a) and marginal part (b) of quartz porphyry cut by later black veinlets. (c) Proximal reddish brown garnet-rich skarn with cavity free. (d) Distal greenish garnet \pm pyroxene skarn with a lot of cavities filled by later calcite. (e) Wollastonite-rich skarn beyond garnet and pyroxene skarn. (f) Highly siliceous hornfels beyond wollastonite-rich skarn. Abbreviations: $q \mathrm{qz}=$ quartz, $\mathrm{fsp}=$ feldspar, grt $=$ garnet, $\mathrm{pyx}=$ pyroxene, $\mathrm{cal}=$ calcite, $\mathrm{wo}=$ wollastonite, $\mathrm{chl}=$ chlorite . cradle into water. The specimens were removed and dried using a moist cloth to remove only surface water and then the $\mathrm{M}_{\text {sat }}$ was measured.

\subsection{Electrical Resistivity}

The resistivity is a function of the rock composition (metallic or conductive minerals) and physical property (pore fluids, porosity, etc.) of the rock. Two other factors must be quantified to evaluate the resistivity, including the length and crosssectional area of the sample being measured. The resistivity is expressed by Ohm's law as follows (3):

$$
\rho=R \frac{S}{L},
$$

where, $\rho$ is resistivity (ohm-m), R is resistance (ohm), $S$ is cross-section area $\left(\mathrm{m}^{2}\right), \mathrm{L}$ is length $(\mathrm{m})$.

Specimens for measuring resistivity were completely saturated by sodium chloride solution, and the resistivity was measured by a system of Park and Matsui (1998). A Handy Viewer MINI-OHM (OYO Corp.) that can transmit constant currents ranging from 10 to $1,000 \mu \mathrm{A}$ was used and resistivity was measured within 30 seconds to avoid drying of the surface with lapse of time.

\subsection{Seismic Velocity}

The seismic velocity (e.g., P wave) generally depends on porosity, lithification, and fluid saturation of rocks, and the values for crustal rocks vary broadly in relation to their rock

Table 1. Representative electron microprobe analyses of garnet from the Wondong deposit

\begin{tabular}{|c|c|c|c|c|c|c|c|c|c|c|}
\hline "Sample No. & "WG24 & "WG25 & "WG26 & 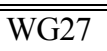 & "WG28 & "WG29 & "WG30 & "WG31 & WG32 & "WG33 \\
\hline Position & core & rim & core & rim & core & rim & core & rim & core & rim \\
\hline \multicolumn{11}{|l|}{ (Weight \%) } \\
\hline $\mathrm{SiO}_{2}$ & 36.3 & 36.5 & 36.2 & 36.5 & 36.6 & 36.4 & 35.8 & 36.0 & 37.1 & 35.6 \\
\hline $\mathrm{TiO}_{2}$ & 1.2 & 0.6 & 0.1 & 0.1 & 1.0 & 0.2 & 0.0 & 0.0 & 0.0 & 0.0 \\
\hline $\mathrm{Al}_{2} \mathrm{O}_{3}$ & 16.4 & 16.7 & 5.4 & 3.6 & 6.5 & 4.2 & 0.6 & 1.3 & 6.2 & 0.4 \\
\hline $\mathrm{Cr}_{2} \mathrm{O}_{3}$ & 0.1 & 0.0 & 0.0 & 0.0 & 0.0 & 0.0 & 0.0 & 0.0 & 0.0 & 0.0 \\
\hline $\mathrm{Fe}_{2} \mathrm{O}_{3}$ & 4.8 & 5.3 & 23.7 & 26.0 & 21.5 & 25.6 & 29.2 & 28.6 & 22.4 & 30.6 \\
\hline $\mathrm{FeO}$ & 0.0 & 0.0 & 0.0 & 0.0 & 0.0 & 0.0 & 0.0 & 0.0 & 0.0 & 0.0 \\
\hline $\mathrm{MnO}$ & 0.2 & 0.3 & 0.2 & 0.1 & 0.3 & 0.1 & 0.4 & 0.4 & 0.2 & 0.2 \\
\hline $\mathrm{MgO}$ & 1.4 & 1.6 & 0.1 & 0.1 & 0.3 & 0.1 & 0.5 & 0.4 & 0.2 & 0.4 \\
\hline $\mathrm{CaO}$ & 36.7 & 36.6 & 36.1 & 35.2 & 35.7 & 35.5 & 34.3 & 33.8 & 35.7 & 34.8 \\
\hline Total & 97.1 & 97.6 & 101.8 & 101.6 & 101.8 & 102.1 & 100.9 & 100.5 & 101.9 & 102.0 \\
\hline \multicolumn{11}{|l|}{ (Mole \%) } \\
\hline Prp & 5.3 & 5.7 & 0.3 & 0.5 & 1.3 & 0.4 & 2.1 & 1.8 & 0.7 & 1.5 \\
\hline Alm & 0.0 & 0.0 & 0.0 & 0.0 & 0.0 & 0.0 & 0.0 & 0.0 & 0.0 & 0.0 \\
\hline Grs & 82.4 & 80.1 & 30.6 & 21.8 & 35.2 & 23.6 & 9.9 & 10.6 & 33.4 & 7.3 \\
\hline Sps & 0.5 & 0.6 & 0.5 & 0.2 & 0.6 & 0.2 & 0.9 & 0.9 & 0.5 & 0.5 \\
\hline Adr & 11.9 & 13.6 & 68.6 & 77.5 & 62.9 & 75.7 & 87.1 & 86.7 & 65.3 & 90.7 \\
\hline
\end{tabular}

Abbreviations: $\mathrm{Adr}=$ andradite, $\mathrm{Alm}=$ almandine, $\mathrm{Grs}=$ grossular, $\operatorname{Prp}=$ pyrope, $\mathrm{Sps}=$ spessartine . 

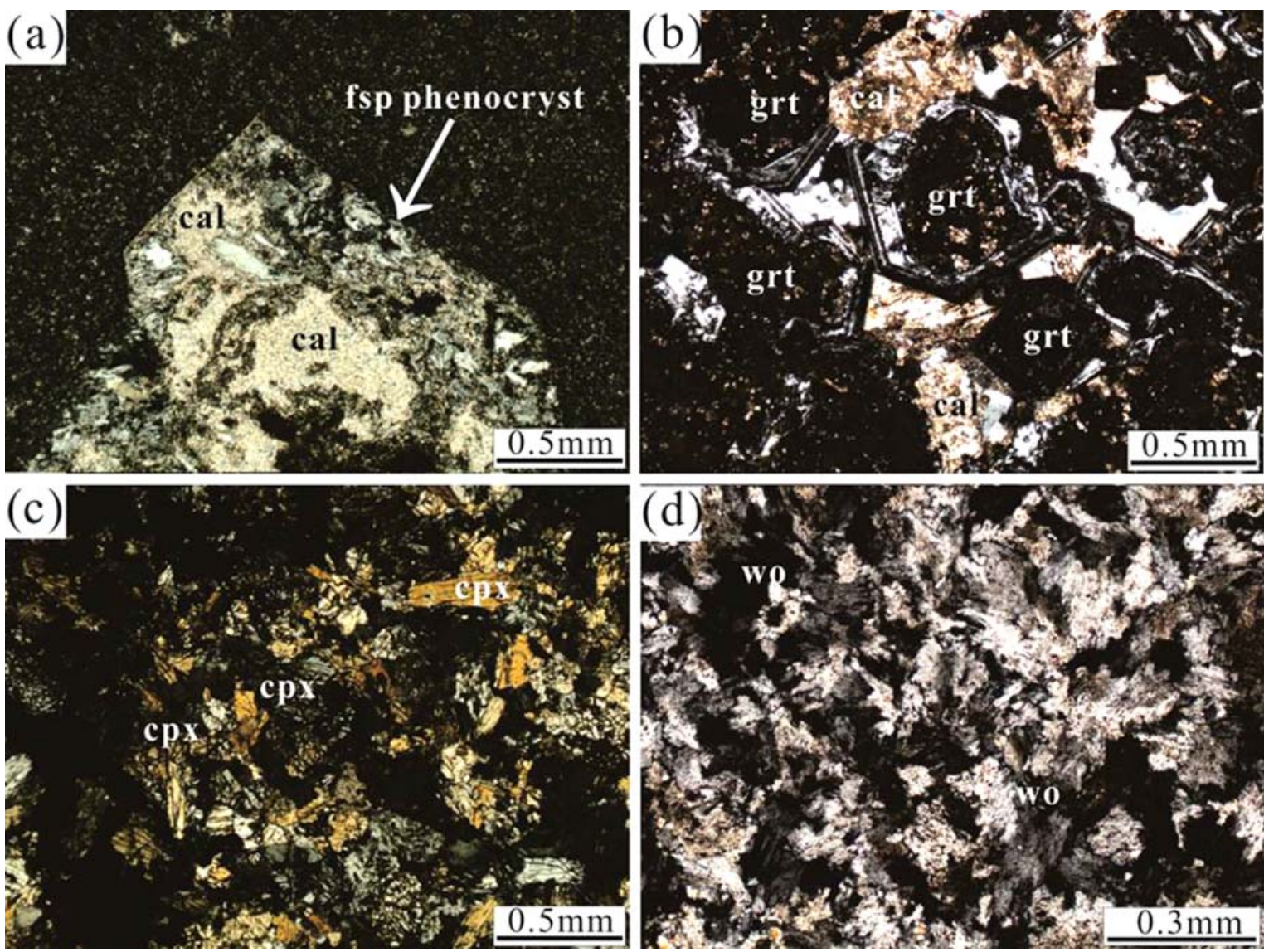

Fig. 6. Photomicrographs showing mineralogy of quartz porphyry and skarn in the Wondong deposit. (a) Quartz phenocryst in quartz porphyry partially altered to calcite. (b) Skarn garnet with overgrowth of andraditic garnet rim, suggesting fluid overprinting. (c) Occurrence of pyroxene beyond garnet-rich zone. (d) Wollastonite-rich skarn beyond garnet \pm pyroxene zone. Abbreviations are same as those in Figure 5 except cpx (= clinopyroxene).

Table 2. Representative electron microprobe analyses of pyroxene from the Wondong deposit

\begin{tabular}{cccccccccc}
\hline \hline Sample No. & WC11 & WC12 & WC13 & WC14 & WC15 & WC16 & WC17 & WC18 & WC19 \\
\hline (Weight \%) & & & & & & & & & \\
$\mathrm{SiO}_{2}$ & 52.0 & 51.9 & 54.6 & 54.2 & 52.7 & 53.3 & 53.2 & 54.6 & 54.5 \\
$\mathrm{TiO}_{2}$ & 0.1 & 0.2 & 0.0 & 0.0 & 0.0 & 0.1 & 0.0 & 0.0 & 0.0 \\
$\mathrm{Al}_{2} \mathrm{O}_{3}$ & 3.6 & 3.3 & 0.6 & 0.4 & 0.6 & 1.0 & 0.5 & 0.2 & 0.2 \\
$\mathrm{Fe}_{2} \mathrm{O}_{3}$ & 0.0 & 0.0 & 0.0 & 0.0 & 0.0 & 0.0 & 0.0 & 0.0 & 0.0 \\
$\mathrm{Cr}_{2} \mathrm{O}_{3}$ & 0.0 & 0.1 & 0.0 & 0.0 & 0.0 & 0.0 & 0.0 & 0.0 & 0.0 \\
$\mathrm{FeO}$ & 4.0 & 4.2 & 0.9 & 5.1 & 6.4 & 4.7 & 6.3 & 3.1 & 2.7 \\
$\mathrm{MnO}$ & 0.2 & 0.2 & 0.3 & 0.7 & 0.8 & 0.6 & 0.9 & 0.7 & 0.5 \\
$\mathrm{MgO}$ & 14.1 & 14.4 & 17.2 & 14.5 & 13.9 & 14.3 & 13.9 & 15.9 & 16.0 \\
$\mathrm{CaO}$ & 25.1 & 25.3 & 26.8 & 26.1 & 26.0 & 25.9 & 26.0 & 26.2 & 26.5 \\
$\mathrm{Na} 2$ & 0.4 & 0.4 & 0.1 & 0.0 & 0.0 & 0.0 & 0.0 & 0.0 & 0.0 \\
$\mathrm{~K}_{2} \mathrm{O}$ & 0.0 & 0.0 & 0.0 & 0.0 & 0.0 & 0.0 & 0.0 & 0.0 & 0.0 \\
$\mathrm{Total}$ & 99.7 & 99.9 & 100.5 & 101.0 & 100.5 & 100.0 & 100.8 & 100.7 & 100.4 \\
\hline Mole $\%)$ & & & & & & & & & \\
Jo & 0.9 & 0.8 & 0.9 & 2.3 & 2.5 & 2.1 & 2.8 & 2.1 & 1.7 \\
$\mathrm{Di}$ & 85.5 & 85.3 & 96.2 & 81.5 & 77.4 & 82.6 & 77.5 & 88.3 & 89.7 \\
$\mathrm{Hd}$ & 13.6 & 13.9 & 2.9 & 16.1 & 20.0 & 15.3 & 19.7 & 9.6 & 8.6 \\
\hline
\end{tabular}

Abbreviations: $\mathrm{Di}=$ diopside, $\mathrm{Hd}=$ hedenbergite, $\mathrm{Jo}=$ johansenite. 


\begin{tabular}{|l|c:c|}
\hline Mineral & Replacement & Filling \\
\hline Garnet & Pyroxene & \\
Wollastonite & \\
Chlorite & & \\
Calcite & & \\
Quartz & \\
Magnetite & \\
Chalcopyrite & & \\
Pyrite & & \\
Sphalerite & & \\
Galena & & \\
Pyrrhotite & & \\
Arsenopyrite & & \\
Bismuth & & \\
\hline
\end{tabular}

Fig. 7. Paragenetic sequence diagram of the Wondong skarn deposit.

type. The $\mathrm{P}$ wave velocity is defined as follows (4):

$$
\mathrm{V}_{\mathrm{P}}=\mathrm{L} /\left(\mathrm{T}_{\mathrm{m}}-\mathrm{T}_{\mathrm{d}}\right)
$$

where, $V_{P}$ is $=p$ wave velocity $(\mathrm{km} / \mathrm{s})$, $\mathrm{L}$ is length of sample $(\mathrm{mm}), \mathrm{T}_{\mathrm{m}}$ is measured transit time $(\mu \mathrm{s})$, and $\mathrm{T}_{\mathrm{d}}$ is system delay $(\mu s)$.

Specimens for measuring $\mathrm{P}$ wave velocity were dried for 24 hours at a temperature of $110^{\circ} \mathrm{C}$ because $\mathrm{P}$ wave velocity of rocks is affected by the type of pore fluid. The $\mathrm{P}$ wave velocity was then measured using the system of Lee et al. (2010). A load cell weighing $20 \mathrm{~kg}$ was used and the travel time of $\mathrm{P}$ waves in the specimens was automatically recorded at intervals of 6 seconds for 2 minutes.

\section{PHYSICAL PROPERTIES OF ROCKS}

The physical properties of rocks from the Wondong skarn deposit are listed in Table 3 . The density is closely related to specific gravity of its comprising minerals (Fig. 8a). Garnet-rich and garnet \pm pyroxene skarn are significantly denser $\left(3.3-3.4 \mathrm{~g} / \mathrm{cm}^{3}\right)$ than quartz porphyries $\left(<2.5 \mathrm{~g} / \mathrm{cm}^{3}\right)$, wollastonite-rich skarn rocks $\left(2.7-3.0 \mathrm{~g} / \mathrm{cm}^{3}\right)$, and silicic hornfels $\left(2.6-2.9 \mathrm{~g} / \mathrm{cm}^{3}\right)$. The skarn is mostly composed of garnet and pyroxene with lesser calcite and chlorite. In this study, specimens of skarn contain a little of ore minerals such as Fe-oxides and sulfides, which have high specific gravities. Thus, the skarn is much denser than surrounding rocks due to the presence of ore minerals in addition to garnet and pyroxene.

The porosity of garnet-rich and garnet \pm pyroxene skarn (up to $8.4 \%$ ) is much higher than other rocks, including quartz porphyry $(0.8-2.5 \%)$, wollastonite-rich skarn (4.1-5.9\%), and silicic hornfels (1.3-3.3\%). It gradually increases from quartz porphyry to skarn, and decreases toward silicic hornfels (Table 3; Fig. 8b). In contrast, garnet-rich and garnet \pm pyroxene skarns show a remarkably lower electrical resistivity (mostly 211-848 $\Omega \mathrm{m}$, except 1,566, 4,180 $\Omega \mathrm{m}$ ) than the rocks such as quartz porphyry $(2,531-8,195 \Omega \mathrm{m})$ and silicic hornfels $(1,815$ and $8,601 \Omega \mathrm{m})$. It clearly shows an opposite pattern to their porosity and tends to decrease from quartz porphyry to skarn, and increase from skarn to silicic hornfels (Table 3; Fig. 8c). The wide range of resistivity of the quartz porphyry would be caused by strong fractures and joints, which were filled with the later quartz-calcite and quartz veins.

The $\mathrm{P}$ wave velocity shows a similar pattern to electrical resistivity (Fig. 8d). High $\mathrm{P}$ wave velocity of quartz porphyry

Table 3. Geophysical properties of various rock types from the Wondong deposit

\begin{tabular}{|c|c|c|c|c|c|c|c|c|c|c|c|c|c|}
\hline \multirow{2}{*}{$\begin{array}{l}\text { Rock } \\
\text { type }\end{array}$} & \multirow{2}{*}{$\begin{array}{l}\text { Depth } \\
\text { (m) }\end{array}$} & \multirow{2}{*}{$\begin{array}{l}\text { Density } \\
\left(\mathrm{g} / \mathrm{cm}^{3}\right)\end{array}$} & \multirow{2}{*}{$\begin{array}{l}\text { Porosity } \\
(\%)\end{array}$} & \multicolumn{7}{|c|}{ Magnetic susceptibility $\left(10^{-5} \mathrm{SI}\right)$} & \multirow{2}{*}{$\begin{array}{c}\text { Resistivity } \\
(\Omega \mathrm{m})\end{array}$} & \multirow{2}{*}{$\begin{array}{c}\text { P wave } \\
\text { velocity }(\mathrm{m} / \mathrm{s})\end{array}$} & \multirow{2}{*}{ Mineral assemblage } \\
\hline & & & & 1 & 2 & 3 & 4 & 5 & 6 & Mean & & & \\
\hline QP & 65.0 & 2.5 & 2.5 & 0 & 1 & 13 & 1 & 1 & 1 & 3 & 2,531 & 4,669 & qtz-or \pm ser \pm cal \\
\hline QP & 67.3 & 2.5 & 0.8 & 1 & 1 & 1 & 1 & 2 & 0 & 1 & 8,195 & 5,420 & qtz-or \pm ser \pm cal \\
\hline QP & 113.7 & 2.5 & 1.6 & 0 & 0 & 0 & 0 & 0 & 1 & 0 & 4,440 & 4,783 & qtz-or \pm ser \pm cal \\
\hline GS & 126.8 & 3.3 & 2.0 & 38 & 35 & 56 & 79 & 33 & 56 & 52 & 4,180 & 5,198 & grt \pm cal \\
\hline GS & 127.4 & 3.3 & 3.0 & 35 & 35 & 51 & 52 & 28 & 80 & 49 & 585 & 4,483 & grt \pm cal \\
\hline GS & 133.5 & 3.4 & 8.0 & 150 & 123 & 110 & 127 & 126 & 171 & 140 & 763 & 2,902 & grt \pm cal \\
\hline GS & 137.2 & 3.4 & 1.8 & 139 & 124 & 94 & 111 & 132 & 134 & 128 & 551 & 4,907 & grt \pm cal \\
\hline GS & 140.7 & 3.3 & 5.0 & 109 & 78 & 77 & 78 & 71 & 114 & 92 & 211 & 3,248 & grt \pm cal \\
\hline GPS & 142.8 & 3.4 & 7.7 & 144 & 130 & 59 & 75 & 117 & 119 & 112 & 431 & 1,534 & grt \pm pyx \\
\hline GPS & 143.0 & 3.3 & 8.4 & 100 & 105 & 87 & 86 & 127 & 142 & 112 & 447 & 1,487 & grt \pm pyx \\
\hline GPS & 144.8 & 3.3 & 4.5 & 159 & 82 & 69 & 114 & 86 & 123 & 110 & 465 & 3,674 & grt \pm pyx \\
\hline WS & 148.3 & 2.7 & 5.9 & 18 & 18 & 9 & 11 & 15 & 18 & 15 & 848 & 3,244 & wo-chl \\
\hline WS & 153.0 & 3.0 & 4.1 & 23 & 13 & 20 & 13 & 15 & 56 & 24 & 1,566 & 3,573 & wo-chl \\
\hline $\mathrm{SH}$ & 158.3 & 2.6 & 3.3 & 8 & 3 & 9 & 10 & 3 & 3 & 6 & 1,815 & 4,282 & qtz-pyx \\
\hline $\mathrm{SH}$ & 172.9 & 2.9 & 1.3 & 35 & 21 & 19 & 20 & 21 & 27 & 25 & 8,601 & 5,590 & qtz-pyx \\
\hline
\end{tabular}

Abbreviations: $\mathrm{QP}=$ quartz porphyry, GS = garnet-rich skarn, GPS = garnet \pm pyroxene skarn, $\mathrm{WS}=$ wollastonite-rich skarn, $\mathrm{SH}=$ siliceous hornfels, or $=$ orthoclase, ser $=$ sericite. Others are same as those in Figure 5. 

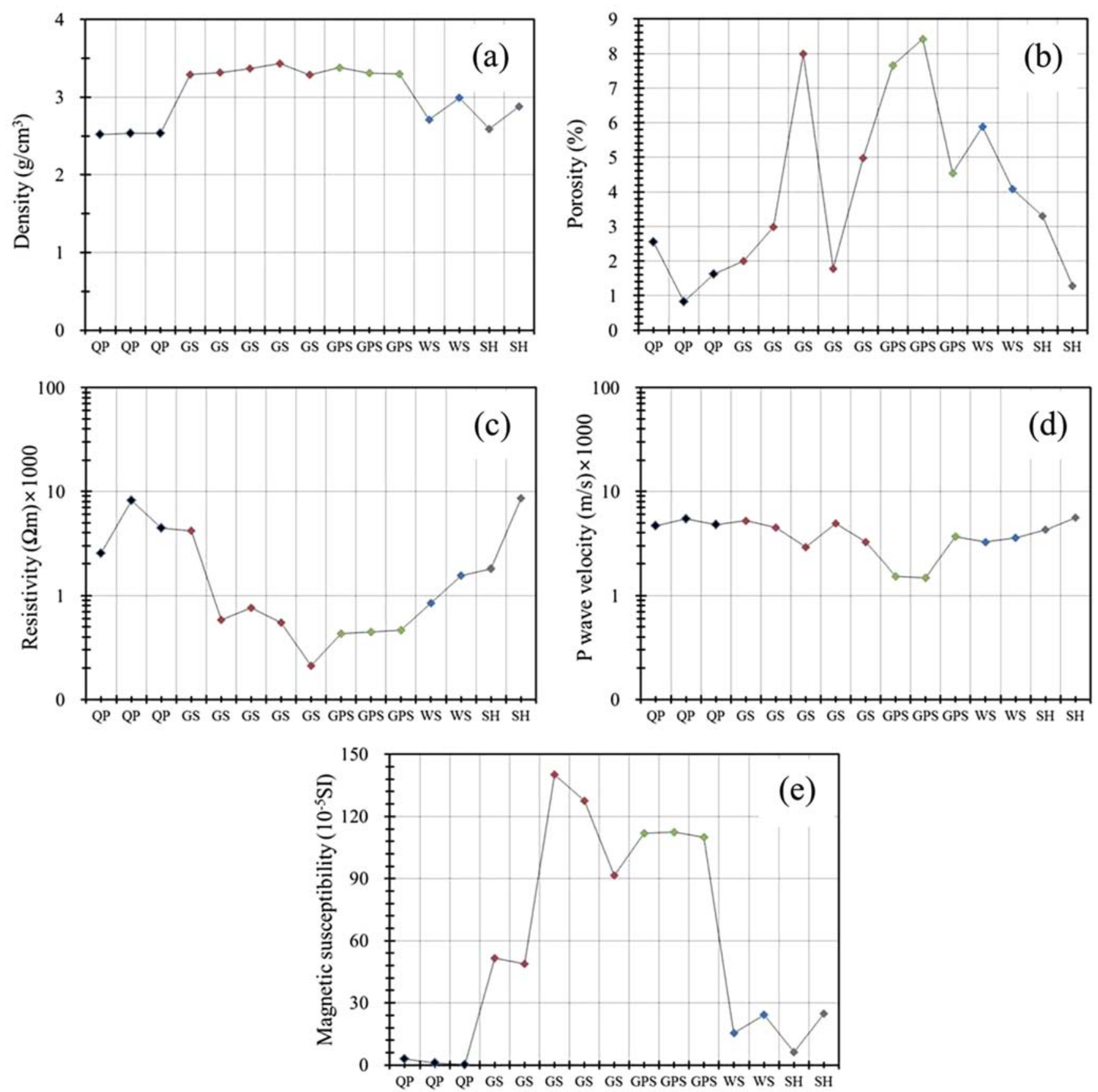

Fig. 8. The variation of density (a), porosity (b), electrical resistivity (c), and P-wave velocity (d), and magnetic susceptibility (e) of the intrusive, skarn rocks, and hornfels plotted as a function of distance to the contact with intrusive rock. Abbreviations are same as those in Table 3.

$(4,699-5,420 \mathrm{~m} / \mathrm{s})$ and garnet-rich skarn $(2,902-5,198 \mathrm{~m} / \mathrm{s})$ tends to decrease toward garnet \pm pyroxene skarn $(1,487-$ $3,674 \mathrm{~m} / \mathrm{s})$, and increases toward silicic hornfels $(4,282-$ $5,590 \mathrm{~m} / \mathrm{s})$. The magnetic susceptibility varies in a broad range $\left(<140 \times 10^{-5} \mathrm{SI}\right.$ in average). Garnet-rich and garnet \pm pyroxene skarn show significantly higher magnetic susceptibility $\left(49-140 \times 10^{-5} \mathrm{SI}\right)$ than the other rocks, including quartz porphyry $\left(<3 \times 10^{-5} \mathrm{SI}\right)$, wollastonite-rich skarn $\left(15-24 \times 10^{-5}\right.$ $\mathrm{SI})$, and silicic hornfels $\left(6-25 \times 10^{-5} \mathrm{SI}\right)$ (Table 3 ; Fig. $\left.8 \mathrm{e}\right)$.

\section{DISCUSSION}

\subsection{Calc-silicate Alteration and Mineralization}

In the Wondong $\mathrm{Fe}-\mathrm{Pb}-\mathrm{Zn}$ polymetallic deposit, there is a general zoning pattern of a proximal reddish-brown garnetrich zone, distal greenish garnet \pm pyroxene zone, and a wollastonite-rich zone at the marble front, resulting from the transfer of heat and fluid from the intrusive rocks to the 
surrounding rocks. This is a typical zoning pattern for most oxidized calcic skarn (Meinert, 1997). The exsoskarn is dominant, whereas there is subordinate endoskarn. The proximal garnet-rich skarn consists mostly of andraditic-grossularitic garnet with lesser calcite and quartz, and the ratio of garnet: pyroxene tends to decrease with increasing distance from quartz porphyry, as many skarn deposits exhibit the change of garnet/pyroxene ratios as a function of distance from intrusive rocks (e.g., Carr Fork, Bingham; Atkinson and Einaudi, 1978, Fortitude skarn; Meyers and Meinert, 1991). The garnet \pm pyroxene skarn is remarkably narrow compared to the garnet-rich skarn zone in the Wondong deposit, though pyroxene is the most abundant mineral in skarn deposits (Atkinson and Einaudi, 1978; Meyer and Meinert, 1991), depending on the causative magma and host rock compositions.

The spatially separated mineralization in skarn deposits from $\mathrm{Fe}$ in the proximal garnet-rich zone to $\mathrm{Pb}-\mathrm{Zn}$ in and beyond the garnet \pm pyroxene zone is generally controlled by magma composition, temperature variation of skarn-forming fluids caused by wall-rock interaction, and oxidation state. For example, Chang and Meinert (2008) reported that high $\mathrm{F}$ content in magma controlled development of endoskarn by decreasing the solidus temperature of the magma and transportation distance of $\mathrm{Zn}$ by hydrothermal fluid. In another example, Reed et al. (2013) reported that decreasing temperature of the hydrothermal fluid caused zoned mineralization from proximal $\mathrm{Cu}-\mathrm{Mo}$ to distal $\mathrm{Pb}-\mathrm{Zn}$ in the Butte porphyry $\mathrm{Cu}-\mathrm{Mo}$ deposit. The typical zonation pattern in the Wondong skarn deposit is probably due to the relatively lower solubility of $\mathrm{Fe}$ oxides compared with $\mathrm{Pb}-\mathrm{Zn}$ sulfides. Therefore, declining temperature, accompanied by water-rock interaction, is likely to be the major cause of most metal deposition in the Wondong skarn system, resulting in the spatial separation of proximal $\mathrm{Fe}$ and distal $\mathrm{Pb}-\mathrm{Zn}$ mineralization.

\subsection{Formation and Importance of Porosity in Rocks}

Metasomatism producing skarn affects both porosity and permeability of rocks from the skarn environment. For example, reactions related to creating garnet may generate porosity (Meinert et al., 2005). Another process is related to decarbonation such as wollastonite- and diopside-forming reactions, which lead to removal of $\mathrm{CO}_{2}$ gas from limestone, although the hydrothermal fluid, originated from the magma, provides a lot of $\mathrm{Si}, \mathrm{Fe}$, and $\mathrm{Al}$. For example, the formation of wollastonite at Mineral Hill, British Columbia, created porosity of host rock by metasomatism (McConaghy, 2001). The mass balance calculations exhibit a large loss of $\mathrm{CaO}$ and $\mathrm{CO}_{2}$ from metacarbonate xenoliths in the Quérigut massif (Durand et al., 2009). The large loss of $\mathrm{CaO}$ and $\mathrm{CO}_{2}$ from host rocks during metasomatism may result in forming considerable cavities in skarn.

The infilling of porosity by garnet growth is commonly observed in outcrop exposures and drill cores from the Wondong skarn deposit (Fig. 6b). Lower porosity in the garnet-rich skarn zone tends to increase towards the garnet \pm pyroxene skarn zone (Fig. 8b; Table 3). Garnet growth suggests that the porosity may have focused skarn-forming fluids and it was filled by later garnet growth (Fig. 6b) and calcite (Fig. 5d). Ore minerals such as chalcopyrite, galena, sphalerite, and magnetite filled this porosity as well. The above mineral occurrences indicate that the porosity played an important role in focusing fluid flow away from the intrusive rocks.

\subsection{Characteristics of Rock Physical Properties}

In general, skarn deposits show complex geophysical signatures such as density, porosity, and electrical resistivity affected by metasomatism between fluid and wall-rock. The higher density of skarn compared to surrounding rocks is mostly related to the relatively higher specific gravity of skarn minerals, such as garnet and pyroxene, which is apparent in skarn specimens in this study, containing only a small quantity of ore minerals, such as Fe-oxides and sulfides. Most geophysical studies on skarn have focused on ore minerals (Chapman and Thompson, 1984; Chapman et al., 1986; Emerson, 1986), which are the major cause of gravitational anomalies. However, in this study, skarn silicate minerals may form a gravitational anomaly and/or seismic discontinuity by itself, even when lacking ore minerals.

Electrical methods are generally referred to as "resistivity surveys" and Fe-oxides and sulfides are commonly regarded as relatively good conductors of electricity. In contrast, rockforming minerals are generally poor conductors. The fact forms the basis for geophysical exploration methods. But our study reveals that the porosity, created by metasomatism, can induce differences of electrical resistivity between skarn and surrounding rocks (Table 3; Fig. 8c). In addition, lower $\mathrm{P}$ wave velocity of garnet \pm pyroxene skarn compared to surrounding rocks was also affected by their porosity (Table 3 ; Fig. 8d).

Rocks from the Wondong deposit also show variable magnetic susceptibilities. In general, the magnetic susceptibility is strongly controlled by the array of Fe-bearing minerals, especially magnetite (Emerson, 1986). Much higher magnetic susceptibilities in the rocks such as garnet-rich and garnet \pm pyroxene skarns in the Wondong deposit are closely associated with abundant occurrence of magnetite than the other rocks (Fig. 4c), and the result is consistent with the total Fe contents of whole-rock composition obtained by XRF analyses, which are $4.8-18.3 \mathrm{wt} \% \mathrm{Fe}_{2} \mathrm{O}_{3}$ for garnet-rich and garnet \pm pyroxene skarns and below $3.1 \mathrm{wt} \%$ for the other rocks (Table 4). Therefore, the physical properties such as density, porosity, electrical resistivity, magnetic susceptibility, and $\mathrm{P}$ wave velocity of rocks from the skarn environment reflect their mineral assemblages, and they can be used for mineral exploration of skarn deposits. 
Table 4. Major element analyses of various rock types from the Wondong deposit

\begin{tabular}{|c|c|c|c|c|c|c|c|c|c|c|}
\hline Rock Type & \multicolumn{3}{|c|}{ Quartz porphyry } & \multicolumn{2}{|c|}{ Garnet-rich skarn } & \multicolumn{2}{|c|}{ garnet \pm pyroxene skarn } & \multicolumn{2}{|c|}{ "Wollastonite-rich skarn } & \multirow{2}{*}{$\begin{array}{c}\text { Siliceous hornfels } \\
\text { WD3-8 }\end{array}$} \\
\hline Sample No. & WD3-1 & WD3-2 & WD3-3 & WD3-4 & WD11 & WD3-5 & WD15 & WD16 & WD3-6 & \\
\hline$(w t \%)$ & & & & & & & & & & \\
\hline $\mathrm{SiO}_{2}$ & 76.5 & 75.7 & 74.4 & 36.5 & 36.2 & 38.4 & 40.4 & 49.5 & 56.4 & 84.8 \\
\hline $\mathrm{Al}_{2} \mathrm{O}_{3}$ & 12.5 & 12.4 & 13.1 & 12.5 & 14.1 & 6.5 & 3.9 & 1.8 & 7.0 & 2.2 \\
\hline $\mathrm{Fe}_{2} \mathrm{O}_{3}$ * & 0.2 & 0.2 & 0.0 & 6.9 & 4.8 & 16.4 & 18.3 & 1.1 & 3.1 & 0.8 \\
\hline $\mathrm{CaO}$ & 0.5 & 1.0 & 1.2 & 36.2 & 36.9 & 33.6 & 32.7 & 45.5 & 24.3 & 6.3 \\
\hline $\mathrm{MgO}$ & 0.3 & 0.2 & 0.0 & 2.1 & 2.1 & 0.8 & 2.4 & 1.0 & 1.7 & 1.1 \\
\hline $\mathrm{K}_{2} \mathrm{O}$ & 6.9 & 6.7 & 6.7 & 0.0 & 0.0 & 0.0 & 0.0 & 0.0 & 4.8 & 1.7 \\
\hline $\mathrm{Na}_{2} \mathrm{O}$ & 1.8 & 1.9 & 3.4 & $<0.02$ & $<0.02$ & $<0.02$ & $<0.02$ & $<0.02$ & 0.3 & 0.4 \\
\hline $\mathrm{TiO}_{2}$ & 0.1 & 0.1 & 0.0 & 0.4 & 0.4 & 0.5 & 0.1 & 0.2 & 0.5 & 0.4 \\
\hline $\mathrm{MnO}$ & 0.0 & 0.0 & 0.0 & 0.3 & 0.3 & 0.2 & 0.4 & 0.5 & 0.4 & 0.1 \\
\hline $\mathrm{P}_{2} \mathrm{O}_{5}$ & 0.1 & 0.0 & 0.0 & 0.1 & 0.1 & 0.2 & 0.3 & 0.1 & 0.2 & 0.1 \\
\hline L.O.I & 0.8 & 1.5 & 0.8 & 4.6 & 5.2 & 4.0 & 1.9 & 0.4 & 0.8 & 1.8 \\
\hline Total & 99.7 & 99.8 & 99.7 & 99.6 & 100.1 & 100.7 & 100.4 & 100.0 & 99.4 & 99.6 \\
\hline
\end{tabular}

*Total iron as $\mathrm{Fe}_{2} \mathrm{O}_{3}$.

\section{CONCLUSIONS}

The Wondong skarn deposit is related to the intrusion of quartz porphyry and characterized by general zonation comprising a proximal reddish-brown garnet-rich zone, a distal greenish garnet \pm pyroxene zone, and a wollastonite-rich zone at the marble front. The mineralization is characterized by $\mathrm{Fe}$ in the proximal garnet-rich zone and $\mathrm{Pb}-\mathrm{Zn}$ within and beyond the garnet \pm pyroxene zone. Skarn with different contents of Fe-oxides and sulfides is significantly denser than the other rocks such as quartz porphyry and silicic hornfels. The porosity of skarn rocks has a broad range and is also higher than the surrounding rocks. In contrast, most skarn rocks show a remarkably low electrical resistivity than the surrounding rocks. Magnetic susceptibilities are higher in skarn rocks than the surrounding rocks. $\mathrm{P}$ wave velocities in the garnet \pm pyroxene zone at the skarn front show lower values than other rock types. In general, the physical properties such as density, porosity, electrical resistivity, magnetic susceptibility, and $\mathrm{P}$ wave velocity of rocks from the skarn environment reflect their mineral assemblages and thus can be used for mineral exploration of skarn deposits.

ACKNOWLEDGMENTS: This research was supported by the Basic Research Project of the Korea Institute of Geoscience and Mineral Resources (Project No. 15-3220) funded by the Ministry of Science, ICT and Future Planning of Korea. The early version of the manuscript was improved markedly by the thoughtful review of Noel White. We are grateful to anonymous Geoscience Journal reviewers for their detailed and constructive comments, which led to substantial improvements of the manuscript.

\section{REFERENCES}

Akinson, W.W., Jr. and Einaudi, M.T., 1978, Skarn formation and mineralization in the contact aureole at Carr Fork, Bingham,
Utah. Economic Geology, 73, 1326-1365.

Chang, Z. and Meinert, L., 2008, The Empire Cu-Zn mine, Idaho: exploration implications of unusual skarn features related to high fluorine activity. Economic Geology, 103, 909-938.

Chapman, B.H. and Thompson, D. T., 1984, Applications of geophysical logging within skarn-type deposits. Log Analyst, 25, 13-24.

Chapman, R.H, Joseph, S.E., and Campbell, L.G., 1986, Magnetic exploration for skarn deposits, Ivanpah mining district, San Bernardino County, California. California Geology, 39, 171-178.

Chi, S.J., Kang, I.M., Kim, Y.U., Kim, E.J., Kim, I.J., Park, G.S., Park, S.W., Lee, J.H., Lee, J.S., Lee, H.Y., Jin, K.M., Heo, C.H., and Hong, Y.K., 2011, Evaluation of development possibility for the security of industrial mineral resources $(\mathrm{Cu}, \mathrm{Pb}, \mathrm{Zn}, \mathrm{Au}$, etc) on the domestic mines. Report GP2010-024-2011 (2), Korea Institute of Geoscience and Mineral Resources, Daejeon, 355 p.

Choi, D.K., 1988, The Yongwol Group (Cambrian-Ordovician) redefined: a proposal for the stratigraphic nomenclature of the Choson Supergroup. Geosciences Journal, 2, 220-234.

Chough, S.K., Kwon, ST., Ree, J.H., and Choi, D.K., 2000, Tectonic and sedimentary evolution of the Korean Peninsula: A review and new view. Earth-Science Reviews, 52, 175-235.

Durand, C., Marquer, D., Baumgartner, L., Goncalves, P., Boulvais, P., and Rossy, M., 2009, Large calcite and bulk-rock volume loss in metacarbonate xenoliths form the Quérigut massif (French Pyrenees). Contributions to Mineralogy and Petrology, 157, 749-763.

Emerson, D.W., 1986, Physical properties of skarns. Exploration Geophysics, 17, 201-212.

Emerson, D.W. and Welsh, H.K., 1988, Low-frequency permittivities of skarns and associated rocks. Geophysics, 53, 1233-1240.

Geological Investigation Corps of Taebaeksan Region, 1962, Geological map of Taebaeksan region: 9. Yeongweol sheet. Geological Society of Korea.

Hoover, D.B. and Knepper, D.H., 1992, Geophysical model of tin skarn and related deposits. U.S. Geological Survey Open-File Report 92-0557, 89-94.

Ishihara, S., 1977, The magnetite-series and ilmenite-series granitic rocks. Mining Geology, 27, 293-305.

ISRM (International Society for Rock Mechanics), 1979, Suggested 
methods for determining water content, porosity, density, absorption, and related properties and swelling and slake-Durability index properties. International Society for Rock Mechanics, 143-151.

Kim, Y.D., Oh, M.S., Park, N.Y., Kim, J.K., Hwang, D.H., Kim, M.S., Park, S.W., Kim, S.Y., Hong, Y.K., Lee, S.G., and Lim, M.T., 1993, The mineral prospecitngs for the deep seated hidden ore body in Taebaeksan area, the northern part of Baekunsan synclinal area. Korea Institute of Energy and Resources, Daejeon, 110 p.

Lee, S.K., Lee, T.J., and Sung, N.H., 2010, Characteristics of rock samples from Seokmo island using an automated-continuous seismic velocity measuring system. Korean Society for Geosystem Engineering, 47, 756-770.

McConaghy, K.R., 2001, Alteration and infiltration: Documenting controls on skarn formation at Mineral Hill, Sechelt, southwestern British Columbia. Unpublished M.Sc. thesis, University of British Columbia, Vancouver, $120 \mathrm{p}$.

Meinert, L.D., Dipple, G.M., and Nicolescu, S., 2005, World skarn deposits. Economic Geology $100^{\text {th }}$ anniversary volume, 299-336.

Meinert, L.D., 1997, Application of skarn deposit zonation models to mineral exploration. Exploration and Mining Geology, 6, 185-208.

Meyers, G.L. and Meinert, L.D., 1991, Alteration, mineralization, and gold distribution in the Fortitude gold skarn. In: Raines, G.L., Lisle, R.E., Schafer, R.W., and Wilkinson, W.H. (eds.), Geology and ore deposits of the Great Basin. Geological Society of Nevada, Reno, 1, 407-418.

Oh, M.S., Kim, Y.D., Hwang, D.H., Lee, J.H., and Sung, K.S., 1995,
The polymetallic mineral prospecting for the deep seated hidden ore body in the northern part of Baegunsan synclinal zone, Taebaegsan mineralized district, Eastern part of Korea. Report KR94(C)1-6, Korea Institute of Geoscience and Mineral Resources, Daejeon, $127 \mathrm{p}$.

Park, C., Song, Y., Chi, S.J., Kang, I.M., Yi, K., and Chung, D., 2013, $\mathrm{U}-\mathrm{Pb}$ (SHRIMP) and $\mathrm{K}-\mathrm{Ar}$ age dating of intrusive rocks and skarn minerals at the W-skarn in Weondong deposit. Journal of Mineralogical Society of Korea, 26, 161-174.

Park, S.G. and Matsui, T., 1998, Basic study on resistivity of rocks. Butsuri-Tansa, 51, 201-209.

Peng, C. and Zhao, Y., 1998, The deep geophysical background and distribution of auriferous skarn deposits in the middle and lower Yangtze River valley and neighboring areas in China. Geophysical and Geochemical Exploration, 22, 175-182.

Reed, M., Rusk, B., and Palandri, J., 2013, The Butt magmatic-hydrothermal system: One fluid yields all alteration and veins. Economic Geology, 108, 1379-1396.

Spector, A., 1972, Examples of the use of aeromagnetic surveying in the search for porphyry and skarn copper deposits. Society of Exploration Geophysicists, Annual International Meeting, Tulsa, $42,7-8$.

Manuscript received September 23, 2014

Manuscript accepted March 25, 2015 